\title{
Characterization of 'Candidatus Phytoplasma asteris'-related strain association with leaf yellowing of Wrightia antidysenterica (Arctic Snow) in Tripura, India
}

\author{
Y. S. Shreenath ${ }^{1} \cdot$ Amar Bahadur $^{2} \cdot$ Hemavati Ranebennur ${ }^{1} \cdot$ Govind P. Rao ${ }^{1}[0$
}

Received: 11 February 2021 / Accepted: 19 April 2021 / Published online: 30 April 2021

(c) Australasian Plant Pathology Society Inc. 2021

\begin{abstract}
Wrightia antidysenterica is a small compact and evergreen ornamental shrub. Little leaf and yellowing symptoms were recorded on W. antidysenterica plants in June 2018 at College of Agriculture campus, Lembucherra, Tripura. The expected amplicons of $\sim 1.25 \mathrm{~kb}$ and $\sim 80 \mathrm{bp}$ were obtained in symptomatic leaf samples with the phytoplasma specific universal $16 \mathrm{~S}$ rRNA and $\sec A$ gene primers. Sequence comparison analysis of $16 \mathrm{~S}$ rRNA and $\sec A$ gene confirmed the association of ' $\mathrm{Ca}$. P. asteris'-related strain. However, comparing the restriction profiles of 16S rRNA gene in virtual RFLP analysis revealed that the phytoplasma was a $16 \mathrm{SrI}$ group related strain. To our knowledge, this is the first report of phytoplasma association with $W$. antidysenterica little leaf and yellowing in world.
\end{abstract}

Keywords Arctic Snow · In silico RFLP · SecA gene · 16S rRNA gene · 'Ca. P. asteris'

Wrightia antidysenterica (syn: Holarrhena pubescens; Family: Apocynaceae) also known as 'Arctic Snow', is a small, compact and semi-deciduous shrub native to Sri Lanka. It is often grown as an ornamental and valued plant especially for its year-round production of white attractive flowers. During the full bloom, plant is covered with white flowers that look like little stars, and from a distance appears like snowflakes. It is a perfect flower crop for limited space and small gardens that can also be grown as a house plant (Srinroch et al. 2019). The bark plays a major role in medicine with its characteristic anti-microbial and antiinflammatory properties (Wickramaratne et al. 2015). In India, some fungal diseases caused by Sarcinella apocynacearum and Cercospora wrightia are reported which causes leaf spot disease of W. tinctoria (Orwa et al. 2009) but no other disease has been reported on this plant.

Phytoplasmas are reported to be associated with more than 1000 plant diseases worldwide, posing a significant impact on agriculture economics and are transmitted by

Govind P. Rao

gprao_gor@rediffmail.com

1 Division of Plant Pathology, ICAR- Indian Agricultural Research Institute, NewDelhi 1100012, India

2 College of Agriculture, Lembucherra, Tripura, West Tripura 799210, India phloem-sucking leafhopper species (Bertaccini and Lee 2018). Around 172 plant species, including legumes, vegetables, cereals, spices, medicinal plants, trees, ornamentals, cash and oil crops, palms, fruit trees and weeds have been reported to be associated with ten phytoplasma groups in India (Rao 2021). However, six phytoplasma groups (16SrI-B, 16SrII-D, 16SrVI-D, and 16SrXIV-A, 16SrIX and $16 \mathrm{SrXI}$ ) were reported to be associated with ornamental plants from India (Rao 2021). During a survey in June 2018, little leaf and yellowing symptoms were recorded on W. antidysenterica plants planted in the campus area of College of Agriculture, Lembucherra (23.9 N, 91.3E), Tripura, with a symptom incidence of around $60 \%$ (Fig. 1).

The symptomatic (four) and non-symptomatic leaf samples (two) were collected from campus area of College of Agriculture, Lembucherra, Tripura. The Catharanthus roseus infected with aster yellows phytoplasma strain (16SrI; Accession No. CP035949) maintained in the glasshouse was used as a positive control. The DNA was extracted from the petioles and midrib of the infected leaves of both Arctic snow and Catharanthus roseus by CTAB method (Ahrens and Seemüller 1992). The concentration of extracted DNA was quantified using Nanodrop spectrophotometer (ND1000UV/VIS, USA).

The amplification of phytoplasma 16S rDNA was performed with phytoplasma specific universal and nested 
Fig. 1 Wrightia antidysenterica showing healthy a, little leaf and yellowing symptoms $\mathbf{b}$
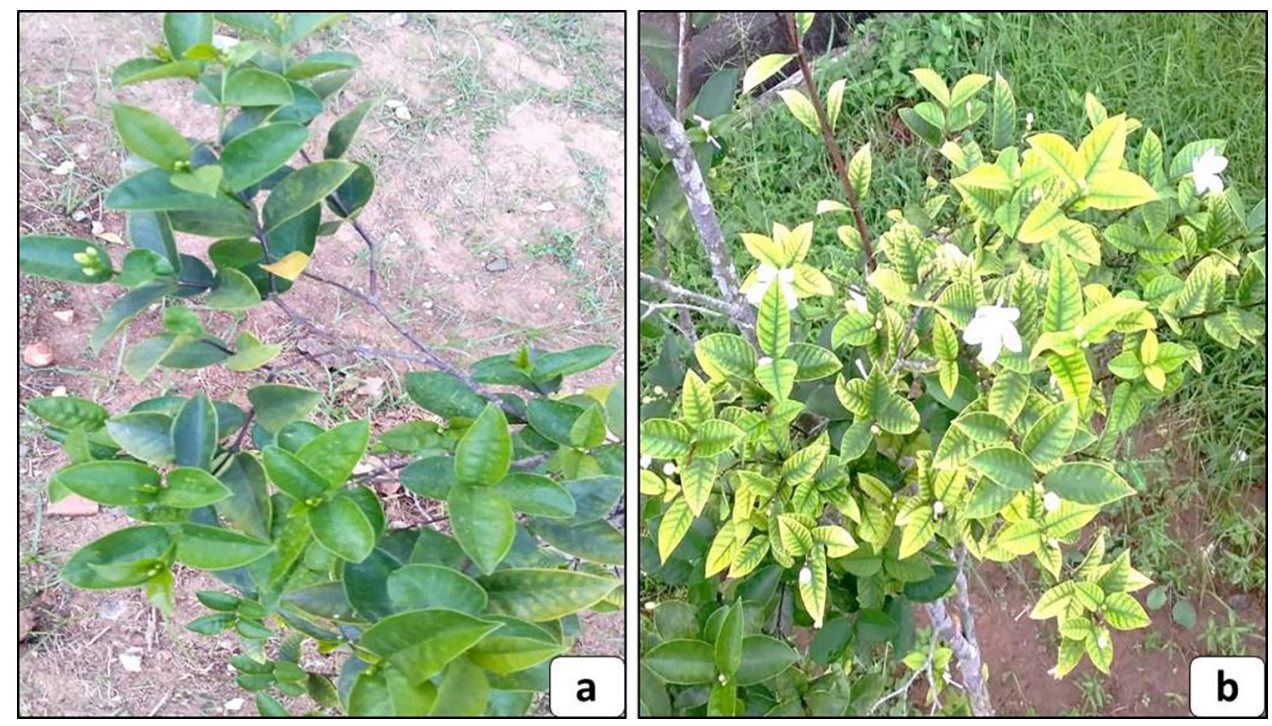

primer pairs, P1/P7 (Deng and Hiruki 1991; Schneider et al. 1995) and R16F2n/R16R2 (Gundersen and Lee 1996), respectively. The components of PCR reactions used per reaction were $18.50 \mu \mathrm{l}$ of nuclease free water, $2.5 \mu \mathrm{l}$ of PCR buffer (10X), $1.5 \mu \mathrm{l}$ of $\mathrm{MgCl}_{2}(25 \mathrm{mM}), 0.5 \mu \mathrm{l}$ of dNTPs $(10 \mathrm{mM}), 0.5 \mu \mathrm{l}$ of each forward / reverse primers $(10 \mathrm{pmol} /$ $\mu \mathrm{l}), 1 \mu \mathrm{l}$ of DNA template (100 ng) and $0.5 \mu \mathrm{l}$ of Taq polymerase (5units/ $\mu \mathrm{l})$. The PCR reactions were carried out in a thermal-cycler (Eppendorf, Germany). For P1/P7 primers, PCR temperature conditions were $94{ }^{\circ} \mathrm{C}, 4 \mathrm{~min}(1 \mathrm{x})$; 30 cycles of $94{ }^{\circ} \mathrm{C}, 45 \mathrm{~s} ; 55^{\circ} \mathrm{C}, 1 \mathrm{~min} ; 72{ }^{\circ} \mathrm{C}, 2 \mathrm{~min}$ and a final extension $72{ }^{\circ} \mathrm{C}, 10 \mathrm{~min}$. This was followed by the dilution (1:30) of the first round PCR product with nuclease free water and used as template in the nested PCR reaction. The PCR cycling conditions for R16F2n/R16R2 were $94{ }^{\circ} \mathrm{C}$, 4 min (1x); 30 cycles of $94{ }^{\circ} \mathrm{C}, 45 \mathrm{~s} ; 56{ }^{\circ} \mathrm{C}, 1 \mathrm{~min} ; 72^{\circ} \mathrm{C}$, $2 \mathrm{~min}$; and a final extension at $72{ }^{\circ} \mathrm{C}(10 \mathrm{~min})$.

For further confirmation of phytoplasma, translocase subunit A, secA universal primers SecAfor1/ SecArev3 (5'GARATGAAAACTGGRGAAGG3'/5'GTTTTRGCA GTTCCTGTCATCC3') followed by semi-nested PCR using SecAfor $2 /$ SecArev3 (5'GATGAGGCTAGAACGCCT 3'/5'GTTTT RGCAGTTCTGTCATCC3') were performed with the following PCR conditions: denaturation at $94{ }^{\circ} \mathrm{C}$ for $2 \mathrm{~min} ; 94{ }^{\circ} \mathrm{C}$ for $30 \mathrm{~s}$, annealing at $53{ }^{\circ} \mathrm{C}$ for $1 \mathrm{~min}$ and extension at $72{ }^{\circ} \mathrm{C}$ for $1 \mathrm{~min}$. The last cycle was extended for an additional $10 \mathrm{~min}$ at $72{ }^{\circ} \mathrm{C}$ (Hodgetts et al. 2008).

Five microlitres of each amplified product were subjected to electrophoresis in a $1.0 \%(\mathrm{w} / \mathrm{v})$ agarose gel, stained with ethidium bromide and observed under UV transilluminator. The amplified PCR products of 16S rRNA and secA gene fragments were purified using the WizardR SV Gel and PCR Clean-up System (Promega, Madison, USA) and were cloned in pGEM-T Easy vector (Promega). Plasmid DNA was extracted, purified and sequenced with primers M13F/
M13R bi-directionally at AgriGenome, Kakkanad, Kerala, India.

The sequences obtained from both the genes, $16 \mathrm{~S}$ rRNA and secA were assembled using Bioedit software (https://bioedit.software.informer.com) and by using ClustalW software, the obtained sequences were aligned with phytoplasma group/subgroup representatives available in GenBank (Hall 1999). The consensus sequences of both the genes 16S rRNA and secA of W. antidysenterica leaf yellow phytoplasma strains (WALY-1 and WALY-2) obtained were submitted to NCBI database. The phylogenetic trees of both the genes were constructed using the neighbor-joining method with MEGA 7.0 (Kumar et al. 2016) using 1000 bootstrap replications. Acholeplasma laidlawii phytoplasma 16S rRNA gene sequence (Acc. no. AB680603) was used to root the trees in phylogeny. The phytoplasma sequences corresponding to the R16F2n/R2 fragments detected in $W$. antidysenterica were subjected to in silico RFLP comparison using the $i$ PhyClassifier (https://plantpathology.ba.ars.usda. gov) online tool and compared with representative sequences of phytoplasma strains of 16SrI group (Zhao et al. 2009).

The presence of phytoplasma association was confirmed by PCR amplifications of cloned fragments of $\sim 1.25 \mathrm{~kb}$ and $\sim 480$ bp from all the symptomatic arctic snow samples with 16S rRNA and secA genes, respectively, while the asymptomatic samples failed to show any amplification product in the PCR assays with either of the primer pairs employed with both the genes discussed above (data not shown).

Pairwise sequence comparison of the partial 16S rRNA gene (Acc. Nos. MW578790 and MW578791) of W. antidysenterica leaf yellow isolates (WALY-1, WALY2) with corresponding regions of different phytoplasma strains retrieved from NCBI database showed 99.68-99.92\% sequence similarity with that of $16 \mathrm{SrI}$ phytoplasma group 
related strains, bitter gourd little leaf phytoplasma (GenBank Acc. No. AB741631), Zinnia elegans yellows phytoplasma (GenBank Acc. No. MN379838) and Toona sinensis phytoplasma (GenBank Acc. No. MH547065). Phylogenetic analysis based on 16S rRNA sequences of $W$. antidysenterica phytoplasma strains also clustered with 16 SrI phytoplasma group related strains (Fig. 2).

Pairwise sequence comparison of the partial secA gene (Acc. Nos. MW559070 and MW559071) sequences of $W$. antidysenterica leaf yellow isolates showed 99.05-99.79\% sequence similarity with that of $16 \mathrm{SrI}$ phytoplasma group related strains, lettuce yellows phytoplasma (GenBank Acc. No. KP662183), sesame phyllody strain (GenBank Acc. No. JN977032) and Elaeis guineensis stunt phytoplasma
(GenBank Acc. No.JF730880). These results were also supported by the corresponding phylogenetic analysis of $\sec$ A gene sequences in which WALY-1 and WALY-2 phytoplasma strains clustered with 16SrI phytoplasma group related strains (Fig. 3). Virtual RFLP analysis of 16S rRNA sequence through $i$ PhyClassifier also confirmed association of $16 \mathrm{SrI}$ group related strain with $W$. antidysenterica in the study (data not shown).

The phytoplasmas diseases are not only damaging the growth and marketing parameters of ornamental plants but also affect their commercial value (Chaturvedi et al. 2010; Bellardi et al. 2018). Knowledge of the importance of phytoplasmas as plant disease agents has advanced rapidly over the last decade with increased significant economic losses

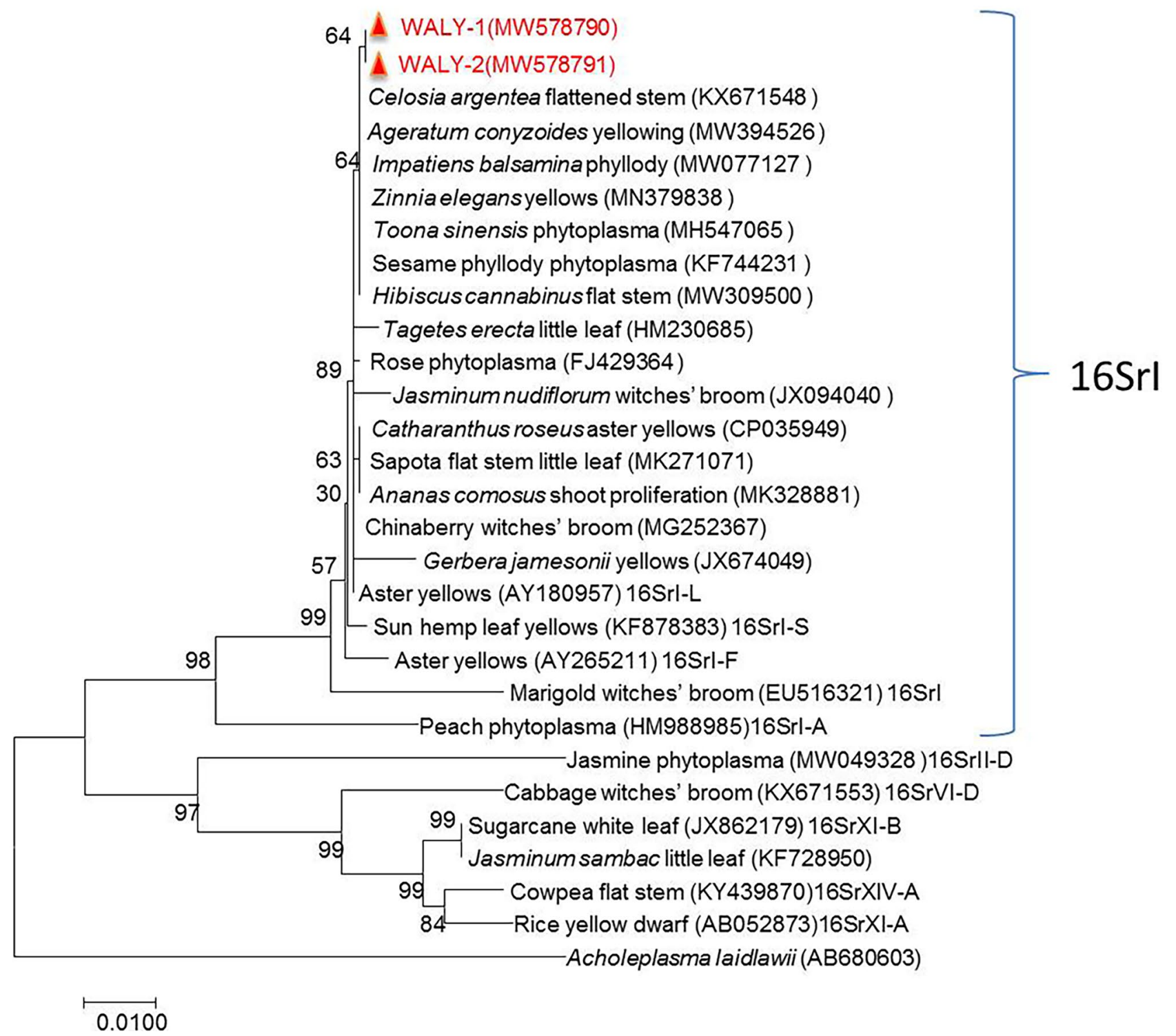

Fig. 2 Phylogenetic tree constructed by the neighbor-joining method using MEGA 7.0, showing the phylogenetic relationship of Wrightia antidysenterica phytoplasma isolates (triangles) from Tripura, India based on sequences of the 16S rRNA gene 


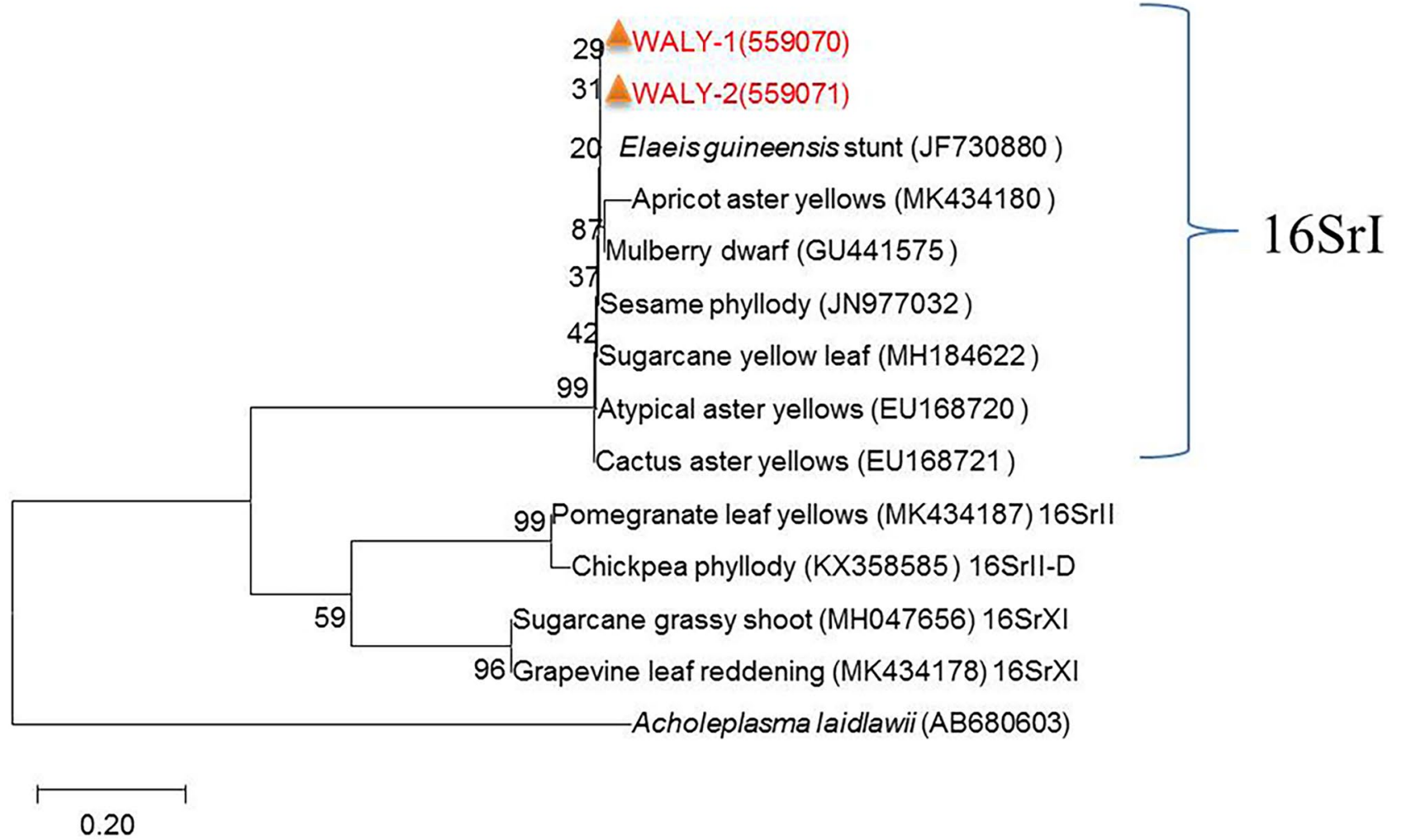

Fig. 3 Phylogenetic tree constructed by the neighbor-joining method, showing the phylogenetic relationship of Wrightia antidysenterica phytoplasma isolates (triangles) from Tripura, India, based on sequences of the $\sec A$ gene

(Bertaccini et al. 2014; Bertaccini and Lee 2018). So far, 74 phytoplasmas belonging to 14 groups were identified in ornamental plants worldwide and six groups (16SrI, 16SrII, 16SrVI, 16SrIX, 16SrXI and 16SrXIV groups) in 34 ornamental species from India. Among them, the 16SrI phytoplasma group was reported to have the broad host range followed by 16 SrII and 16SrVI groups (Rao 2021).

The 16SrI group was identified in several ornamental species in India like rose, Brachycome sp. and petunias (Madhupriya et al. 2013, 2017; Rao et al. 2017). In the present study, we have reported $W$. antidysenterica as additional and new host of ' $C a$. P. asteris' in world. The report of this new host of ' $C a$. P. asteris' has a great epidemiological significance, because this subgroup has already been reported as wide spread strain infecting various plant species in Tripura and other parts of India (Rao et al. 2021) and reported to transmit naturally by different leafhopper species, which can play an important role in natural transmission of this subgroup strain of phytoplasma in several important agricultural crops. Further studies on epidemiology of this strain along with management aspects would be required to check its further spread to other native cultivated crop species.
Acknowledgements The authors are thankful to the DBT, New Delhi, India, for providing financial assistance under the DBT-Twinning Research Project. Also, the authors wish to express sincere thanks to the Principal, College of Agriculture, Lembucherra, Tripura, Head, Division of Plant Pathology, and the Director, Indian Agricultural Research Institute, for providing laboratory and survey facilities.

\section{Declarations}

Ethics approval No ethical issues.

Conflict of interest No potential conflict of interest was reported by the authors.

\section{References}

Ahrens U, Seemüller E (1992) Detection of DNA of plant pathogenic mycoplasma-like organisms by a polymerase chain reaction that amplifies a sequence of the $16 \mathrm{~S}$ rRNA gene. Phytopathol $82: 828-832$

Bellardi MG, Bertaccini A, Rao GP (2018) Phytoplasma diseases in ornamental crops. In Phytoplasmas: plant pathogenic bacteriaI, (pp. 191-233). Springer, Singapore

Bertaccini A, Lee M (2018) Phytoplasmas: an update. In Phytoplasmas: plant pathogenic Bacteria-I (pp. 1-29). Springer, Singapore 
Bertaccini A, Duduk B, Paltrinieri S, Contaldo N (2014) Phytoplasmas and phytoplasma diseases: A severe threat to agriculture. Am J Plant Sci 5:1763-1788. https://doi.org/10.4236/ajps.2014.512191

Chaturvedi Y, Tiwari AK, Rao GP, Duduk B, Bertaccini A (2010) Phytoplasmas on ornamental: detection, diversity and management. Acta Phytopathol Entomol Hung 45(1):31-69

Deng S, Hiruki C (1991) Amplification of 16S rRNA genes from culturable and nonculturable mollicutes. J Microbiol Methods 14:53-61

Gundersen DE, Lee IM (1996) Ultrasensitive detection of phytoplasmas by nested-PCR assays using two universal primer pairs. Phytopathol Mediterr 35:144-151

Hall TA (1999) BioEdit: a user-friendly biological sequence alignment editor and analysis program for windows 95/98/NT. Nucleic Acids Symp Ser 4:95-98

Hodgetts J, Boonham N, Mumford R, Harrison N, Dickinson M (2008) Phytoplasma phylogenetics based on analysis of secA and $23 \mathrm{~S}$ $r R N A$ gene sequences for improved resolution of candidate species of 'Candidatus Phytoplasma'. Int J Syst Evol Microbiol 58:18261837. https://doi.org/10.1099/ijs.0.65668-0

Kumar S, Stecher G, Tamura K (2016) MEGA7: molecular evolutionary genetics analysis version 7.0 for bigger datasets. Mol Biol Evol 33:1870-1874. https://doi.org/10.1093/molbev/msw054

Madhupriya, Namita B, Raju D, Manimekalai R, Rao GP, Khurana SMP (2017) Association of different groups of phytoplasma in flower malformation, phyllody, foliar yellowing, and little leaf disease of rose (Rosa sp.). J Hortic Sci Biotechnol 92(4):424-431

Madhupriya RGP, Khurana SMP (2013) 'Candidatus Phytoplasma asteris' association with leaf yellows and witches broom symptoms of Brachycome species in India. Phytopathogenic Mollicutes 3:91-94. https://doi.org/10.5958/j.2249-4677.3.2.021

Orwa CA, Mutua KR, Jamnadass R, Anthony S (2009) AgroforestreeDatabase: a tree reference and selection guide version 4.0. http:// www.worldagroforestry.org/sites/treedbs/treedatabases.asp

Rao GP (2021) Our understanding about phytoplasma research scenario in India. Indian Phytopathol. https://doi.org/10.1007/ s42360-020-00303-1

Rao GP, Madhupriya TV, Manimekalai R, Tiwari AK, Yadav A (2017) A century progress of research on phytoplasma diseases in India. Phytopathogenic Mollicutes 7:1-38. https://doi.org/10.5958/22494677.2017.00001.9

Schneider B, Seemüller E, Smart CD, Kirkpatrick BC (1995) Phylogenetic classification of plant pathogenic mycoplasma-like organisms or phytoplasma. Molecular and diagnostic procedures in mycoplasmology. J Mol Diagn 1:369-380

Srinroch C, Sahakitpichan P, Techasakul S, Chimnoi N, Ruchirawat S, Kanchanapoom T (2019) 2-Aminobenzoyl and megastigmane glycosides from Wrightia antidysenterica. Phytochem Lett 29:61-64

Wickramaratne MN, Gunatilake LP, Anuradha ND, Godavillathanna AN, Perera MGN, Nicholas I (2015) Antioxidant activity and antibacterial activity of Walidda antidysenterica. Int J Pharmacogn Phytochem 4(2): 121-126

Zhao Y, Wei W, Lee IM, Shao J, Suo X, Davis RE (2009) Construction of an interactive online phytoplasma classification tool, $i$ PhyClassifier, and its application in analysis of the peach X-disease phytoplasma group (16SrIII). Int J Syst Evol Microbiol 59:2582-2593. https://doi.org/10.1099/ijs.0.010249-0 